\title{
Pendidikan Pranatal Perspektif Islam dari Kisah Maryam
}

\author{
Muhammad Shodiq Masrur \\ UIN Sunan Kalijaga Yogyakarta
}

\author{
Keywords: \\ Pendidikan \\ Pranatal, \\ Perspektif Islam, \\ Kisah Maryam
}

\begin{tabular}{l}
\hline *Correspondence \\
Address: \\
masrurshodiq@ \\
gmail.com
\end{tabular}

\begin{abstract}
This article examines the prenatal education of children according to the letter Maryam with the aim of seeing and describing the process of prenatal education that Maryam did to educate the prophet Isa before birth. This research include literature research using descriptive qualitative methods. Data collection in this case prefers to identify discourse from the Alquran, books, journals or other information related to the research title. The data analysis technique used is content analysis of the collected data. The results of this study indicate that the first of the psychological aspects shown by Maryam in the process of prenatal education is always being obedient in worship, dzhikr and having enough rest to stay away from things that can cause stress, in this way it will directly impact the child to worship Allah. Second, the physical aspects shown by Maryam in the prenatal education process can include the stages of choosing a mate who has a religious attitude, the stages of biological relationships and the stages of consumsing nutritious foods (dates). In this way it will have a good impact on the growth and development of fetal life, to the level of intelligence of children after birth.
\end{abstract}

Abstrak: Artikel ini membahas tentang pendidikan pranatal menurut surat Maryam dengan tujuan untuk mendeskripsikan proses pendidikan pranatal yang dilakukan Maryam dalam mendidik nabi Isa sebelum lahir. Penelitian ini termasuk penelitian kepustakaan dengan metode kualitatif deskriptif. Pengumpulan data dalam hal ini lebih diutamakan untuk mengidentifikasi sumber dari Alquran, buku, jurnal, dan informasi lain yang berkaitan dengan tema penelitian. Teknik analisis data yang digunakan adalah analisis isi. Hasil penelitian ini menunjukkan bahwa: Pertama, dari aspek psikologis yang ditunjukkan oleh Maryam dalam proses pendidikan pranatal adalah selalu taat dalam beribadah, berdzikir, dan menjauhi halhal yang dapat menimbulkan stres, dengan cara demikian akan secara langsung berdampak pada anak untuk beribadah kepada Allah. Kedua, aspek fisik yang ditunjukkan oleh Maryam dalam proses pendidikan prenatal meliputi tahapan pemilihan jodoh yang memiliki sikap religius, tahapan hubungan biologis, serta tahapan mengkonsumsi makanan bergizi. Cara ini akan berdampak baik pada tumbuh kembang kehidupan janin, hingga tingkat kecerdasan anak setelah lahir. 


\section{PENDAHULUAN}

Pendidikan pranatal dapat dipahami sebagai usaha sadar dari calon orang tua khususnya ibu dalam membimbing dan memberikan pengajaran kepada janin sampai lahir, dengan tujuan untuk menciptakan kepribadian yang baik seperti kecerdasan emosional dan intelegensi. ${ }^{1}$ Dengan kata lain usaha atau kebiasaan apapun yang dilakukan ibu baik dalam bentuk kebiasaan terpuji ataupun buruk, itulah pendidikan yang diberikan kepada anak yang masih dalam kandungan. Dalam pemahaman yang sama, ada tiga konsep dasar dalam pendidikan anak pranatal diantaranya meliputi pra pernikahan, proses pembuahan dan fase kehamilan.

Pemaknaan "pranatal" terdiri dari dua kata "pra" dan "natal" dengan artian bahwa "pra" diartikan sebelum dan "natal" memiliki makna lahir. Pemaknaan pranatal pada uraian tersebut, pernah diungkapkan oleh Mansur dari bukunya yang berjudul "Mendidik Anak Sejak Dalam Kandungan" bahwa kebiasaan yang menjadi aktifitas manusia dari calon orang tua yang berkaitan dengan segala tingkah laku sebelum melahirkan yang berupa sikap atau karakter dalam rangka memilih pasangan hidup, etika dalam hubungan badan bersama pasangan dalam konteks pernikahan, serta ketaqwaan seorang ibu kepada Allah agar anak terlahir dalam bentuk sehat secara emosional dan kecerdasan. $^{2}$

Apabila pengertian tersebut dikaitkan dengan perspektif pendidikan

1 Robi'ul Nurul Aini Afif, "Implementasi Pendidikan Anak Pranatal," ZAHRA: Research And Tought Elmentary School of Islam Journal, Vol. 1, No. 02 (2020).

2 Mansur, Mendidik Anak Sejak dalam Kandungan (Yogyakarta: Mirta Pustaka, 2006), 16. maka pendidikan anak dari dalam kandungan merupakan usaha sadar calon orang tua untuk mendidik anak dalam bentuk janin yang masih berada di dalam kandungan. Proses pendidikan ini dikhususkan kepada calon orang tua karena anak dalam bentuk janin belum mungkin dididik seperti pembelajaran di dalam kelas, melainkan calon janin harus diberikan materi pendidikan dari calon orang tuanya yang harus menjaga ibadahnya, pola makannya yang mengandungan asupan gizi dan rajin memberikan stimulus atau respon kepada anak yang masih berada di perut ibunya, sehingga ungkapan pendidikan anak sedini mungkin dapat direalisasikan. Pernyataan ini sesuai dengan pendapat para ahli dari Monks dan Haditono bahwa secara biologis hidup manusia dimulai pada saat pembuahan ketika sperma bersatu dengan ovum yang berada di rahim ibu, demikian juga perkembangan psikologi manusia. ${ }^{3}$ Dengan terungkapnya fakta melalui proses penelitian para ahli yang consern dengan dunia pranatal bahwa paradigma lama yang menyatakan rahim ibu adalah ruang tunggu bagi janin yaitu tempat dimana janin hanya menunggu dan tidak melakukan aktivitas apa-apa sampai dia dilahirkan, telah dipatahkan dari hasil penelitian paling mutakhir tentang dunia pranatal menunjukkan bahwa rahim ibu adalah ruang kelas yaitu ruang dimana janin dapat belajar tentang banyak hal, belajar untuk mencapai perkembangan fisik dan psikis secara optimal, serta mengembangkan otak dan saraf bayi sebelum dilhirkan. ${ }^{4}$ Menurut penelitian dari Van De Carr dan Lehrer menyatakan bahwa janin yang berada di dalam

3 Indrijati, Herdina, et.al, Psikologi Perkembangan \& Pendidikan Anak Usia Dini, (Jakarta: Kencana, 2016), 3.

4 Ibid, 4. 
kandungan dapat belajar serta merasakan atau mengetahui perbedaan antara terang dan gelap. Selain itu juga bayi pralahir dapat memperhatikan suara ibu, ayah, saudara, kakek, nenek atau mendengar suara musik merasa sentuhan di perut ibu, bahkan selain itu juga merasakan perubahan emosi sang ibu. ${ }^{5}$ Berdasarkan pernyataan tersebut dapat dipahami bahwa janin yang berada di dalam kandungan telah mampu merespon atau bereaksi terhadap stimulus atau rangsangan dari luar, yang dimulai sejak awal kehidupannya yang ditunjukkan dengan kemampuan janin menciptakan tingkah laku yang bersifat spontan atau perilaku berulang seperti menghisap jari ataupun merespon terhadap sentuhan dan suara-suara yang di dapat dari luar perut ibunya sebagai bentuk rangsangan terhadap janin untuk menerima pelajaran.

Akan tetapi proses pendidikan anak pranatal saat ini, sebagian dari calon orang tua khususnya pasangan suami istri yang masih muda serta belum cukup pengetahuan dan minim pengalaman yang sifatnya pertama kali dalam proses kehamilan, seringkali melupakan proses pendidikan anak pranatal dan calon orang tua belum mengerti bagaimana pendidikan anak pranatal yang perlu dilakukan kepada janin yang berada di perut ibu, sehingga momentum golden age atau periode emas pertumbuhan bagi anak hilang begitu saja. Istilah golden age dapat dipahami sebagai tahapan pertumbuhan dan perkembangan anak yang paling penting pada masa awal kehidupan anak, yang dihitung meliputi 1000 hari dari masa dalam kandungan sampai dengan usia anak mencapai dua

\footnotetext{
5 Ibid, 4.

6 Anwar Mujahidin and Zamzam Farrihatul Khoiriyah, "Konsep Pendidikan Prenatal Dalam
}

tahun. Alhasil dari pernyataan tersebut, apabila periode emas diabaikan dan tidak dilaksanakan dengan baik oleh calon orang tua, maka pertumbuhan dan perkembangan janin yang meliputi kecerdasan emosional dan pembentukan intelegensi bagi anak yang akan lahir tidak terbentuk secara maksimal. Sehingga sudah selayaknya menjadi perhatian bagi calon orang tua. Apabila pendidikan di periode pranatal terdapat keteledoran dalam perawatan terhadap janin yang berada di dalam kandungan akan membawa dampak buruk bagi pertumbuhan dan perkembangannya di kemudian hari.

Dalam pandangan Islam disebutkan bahwa pendidikan prenatal menekankan orang tua untuk mendidik janin pada masa pranatal seperti memelihara batin dari segi psikologis yang damai, bahagia dan tentram agar secara psikologis janin dapat berkembang secara normal dengan cara meningkatkan ibadah dan meninggalkan maksiat terutama bagi calon ibu agar janinnya senantiasa mendapatkan sinaran cahaya dari Allah SWT. Ketaqwaan menentukan kestabilan psikologis calon ibu yang sedang hamil. Ketaqwaan dapat menciptakan kesabaran dan istiqomah dalam menentukan pilihan kehidupan. Kesehatan mental atau rohani manusia akan mudah rapuh apabila kerangka dasar dari perilaku beribadah tidak lagi berkembang dalam pribadinya sehingga mudah diserang oleh penyakit batiniyah yang berasal dari rohaniah ${ }^{6}$.

Meskipun demikian secara umum ilmu yang membahas pendidikan pranatal sudah ada di dalam Alquran. Sebagaimana yang pernah dicontohkan oleh Maryam binti Imran dalam

Perspektif Tafsir Al-Misbah Karya M.Quraish Shihab," Ta'allum: Jurnal Pendidikan Islam, Vol. 06, No. 01 (2018). 
mendidik putranya yang bernama $\mathrm{Nabi}$ Isa AS sejak masih berada di dalam kandungan. Maryam telah berhasil melewati pendidikan pranatal dengan bukti bahwa Nabi Isa As setelah lahir memiliki pertumbuhan dan perkembangan yang sangat baik secara psikologi dan fisik, selain itu Nabi Isa As dapat menjadi anak yang sholeh, bertaqwa dan berbudi luhur serta mempunyai kecerdasan dalam ilmu pengetahuan sehingga mampu menjadi pemimpin dari Bani Israil. Maryam binti Imram ketika mengandung Nabi Isa $A S$ di perutnya selalu melakukan ibadah kepada Allah dalam bentuk dzikir, taat kepada perintah dan laranagan serta menjaga diri dari kekacauan batin seperti menjauhkan diri dan berpuasa bicara dari orang-orang yang dapat menganggu atau mengancam batinya secara psikologis.

Sementara dalam perspektif Alquran pendidikan di masa pranatal dimulai dari pembuahan sperma dan ovum sampai masa kelahiran Pernyataan tersebut sesuai dengan firman Allah dalam Alquran dari surah Al-Mukminun ayat 12-14, disebutkan bahwa proses pranatal yaitu:

"Dan sesungguhnya Kami telah menciptakan manusia dari saripati tanah. Kemudian Kami menjadikan nuthfah dalam tempat yang kokoh. Kemudian Kami ciptakan nuthfah itu alaqah, lalu Kami ciptakan alaqah itu mughdah, lalu Kami ciptakan mughdah itu dengan daging. Kemudian Kami mewujudkannya makhluk lain. Maka Maha banyak keberkahan Allah, pencipta Yang Terbaik".7

7 Departemen Agama Republik Indones, Alquran Dan Terjemahannya, Surat Al-Mu'minun Ayat 12-14 (Jakarta: PT Restu Bumi, 1976-1977.), 527.
M. Quraish Shihab pakar tafsir berpendapat di dalam karyanya yang berjudul Tafsir Al-Misbah bahwa penciptaan manusia memiliki ruh, sifat kemanusiaan, berupa potensi untuk berpengetahuan, mengarungi kedalaman samudra serta menjelajahi angkasa luar. ${ }^{8}$ Pernyataan tersebut dapat terwujud apabila ada peran orang tua yang mampu memelihara dan mendidik anak dari janin hingga sepanjang hayat. Tugas utama dari kedua orang tua bagi pendidikan anak adalah peletak dasar bagi pendidikan akhlak dan pandangan hidup keagamaan. Sifat dan tabiat anak sebagian besar diambil dari kedua orang tuanya dan dari anggota keluarga yang lain. ${ }^{9}$ Sehubungan dengan hal tersebut, calon orang tua harus benarbenar memperhatikan pendidikan anak, sebab anak merupakan amanah dari Allah yang harus dididik agar menjadi anak yang sholeh, bertaqwa dan berbudi luhur serta mempunyai kecerdasan dalam ilmu pengetahuan.

Untuk mencapai tujuan tersebut yang diharapkan adalah calon orang tua harus menjadi pendidik untuk janinya sendiri dan melakukan proses pendidikan pranatal secara maksimal, dikarenakan calon orang tua harus sadar bahwa yang paling bertanggung jawab terhadap pendidikan janin adalah adalah orang tua, keluarga, lingkungan dan masyarakat. Berhasil tidaknya proses pendidikan pranatal juga sangat tergantung pada lingkungan masyarakat untuk menjaga stabilitas psikis calon ibu yang sedang mengandung janinya di perut. Oleh karena itu, keluarga ataupun masyarakat perlu bersikap ramah

8 M. Quraisy Shihab, Tafsir Al-Mishbah (Pesan, Kesan Dan Keserasian Alquran, Vol. 7 (Jakarta: Lentera Hati, 2002), 164-167.

9 Hasbullah, Dasar-Dasar Ilmu Pendidikan (Jakarta: Raja Grafindo Persada, 2009), 38. 
dengan tujuan untuk menumbuh kembangkan potensi psikologis dan inteligensi pada janin. Suasana batin calon ibu sangat tergantung dengan sikap orang-orang terdekat dan masyarakat di sekitar lingkungan.

Dalam era sekarang ini pada kenyataanya pendidikan pranatal kurang mendapatkan perhatian, bahkan lebih cenderung diabaikan seperti kurangnya pemberian asupan yang bergizi selama masa $\operatorname{kehamilan}^{10}$, dan kurangnya memberikan stimulasi pada sel-sel otak janin ${ }^{11}$. Pernyataan tersebut disebabkan karena calon orang tua beranggapan bahwa pendidikan usia dini dimulai ketika anak sudah terlahir dan pertumbuh kembangan janin yang masih berada di rahim sifatnya pertumbuhan secara fisik saja yang dimulai dari gumpalan darah, tulang dan daging yang membungkus tulang, sehingga tidak perlu adanya pendidikan untuk menumbuh kembangkan potensi psikologis dan intelensi pada anak yang belum lahi. Hal itu tentu bertolak belakang dengan penelitian dari Van De Carr dan Lehrer menyatakan bahwa janin yang berada di dalam kandungan dapat belajar serta merasakan atau mengetahui perbedaan antara terang dan gelap. ${ }^{12}$ Bahkan dari Alquran menjelaskan tentang kehidupan pertama dimulai dari dalam kandungan yang berupa janin di perut atau alam kandungan ibunya. Islam juga mengajarkan pendidikan pranatal dan beberapa tahapanya yang dikisahkan dalam kisah Maryam binti Imran. Salah satu tanda kemukjizatan Alquran adalah cara Allah dalam mendidik manusia dengan kisah-kisah yang terdapat di dalam Alquran. Dengan cara itu manusia dapat pelajaran dari pesan-pesan

${ }^{10}$ Aeda Ernawati et al., "Masalah Gizi Pada Ibu Hamil Nutritional Issues Among Pregnant Mothers" Vol. XIII, No. 1 (2019), 60-69. edukatif yang terdapat di dalamnya dan lebih mudah dicerna dan menarik sebab tanpa merasa diindoktrinasi. Berdasarkan pernyataan tersebut penulis tertarik untuk melakukan kajian pendidikan pranatal yang terkandung di dalam kisah Maryam binti Imran.

Masalah yang menjadi fokus kajian penelitian ini adalah bagaimana pendidikan pranatal yang dilakukan Maryam binti Imran dalam mendidik putranya yang bernama Nabi Isa AS yang masih di dalam kandungan. Atas dasar ini, kajian tentang pendidikan pranatal dari kisah Maryam binti Imran perlu dibahas secara mendalam, agar dapat dijadikan sebagai rujukan utama bagi calon orang tua dalam melakukan pendidikan pranatal pada janin-janin mereka yang masih di dalam kandungan, hingga pada akhirnya mereka mampu mengembangkan potensi janin secara psikologis dan intelegensi agar menjadi anak yang sholeh, bertaqwa dan berbudi luhur serta mempunyai kecerdasan dalam ilmu pengetahuan ketika anak sudah terlahir. Hasil penelitian ini di bidang kajian pendidikan pranatal dari kisah Maryam binti Imran diharapkan mampu memberikan sumber rujukan terbaru bagi calon orang tua untuk melakukan proses pendidikan pranatal, sehingga calon orang tua memiliki pengetahuan dan keterampilan dalam mendidik anak yang masih dalam bentuk janin yang berada di alam kandungan perut ibunya.

11 Indrijati, Herdina, et.al., Psikologi Perkembangan \& Pendidikan, 11. 12 Ibid., 3. 


\section{KAJIAN TEORI}

\section{Pendidikan Pranatal}

Fuad Ihsan mengemukakan pendapat bahwa pendidikan merupakan usaha manusia untuk menumbuhkan dan mengembangkan fitrah atau potensi pembawaan yang baik dari aspek jasmani dan rohani yang disesuaikan dengan nilai-nilai yang berlaku di dalam masyarakat dan kebudayaan. ${ }^{13}$ Pendidikan memiliki tujuan untuk menghasilkan generasi yang berilmu pengetahuan dan memiliki karakter yang berbudi pekerti serta beriman yang kuat terhadap sang pencipta. Menurut Hasan Langgulung pelaksanaan pendidikan yang baik dimaknai sebagai hal yang paling penting, karena secara pribadi pendidikan merupakan upaya sadar untuk mengembangkan potensi-potensi anak, sementara secara sosial pendidikan dipahami sebagai upaya untuk mewariskan budaya. ${ }^{14}$ Sementara Nurori Soyomukti menjelaskan dalam makna luas bahwa pendidikan dapat diartikan sebagai dua konsep yaitu long dan life education, dengan pemahaman bahwa pendidikan merupakan usaha sepanjang hayat dengan segala sesuatu dalam kehidupan yang dapat mempengaruhi untuk pembentukan pola berpikir dan berstindak secara individu. ${ }^{15}$ Berdasarkan penjelasan tersebut dapat dipahami bahwa yang memiliki kewajiban pertama kali dalam mendidik di lingkungan keluarga adalah orang tua. Namun perlu dipahami juga bahwa pendidikan tidak selamanya diawali ketika anak sudah terlahir atau menunggu sampai berumur delapan

13 Fuad Ihsan, Dasar-Dasar Pendidikan (Jakarta: Rineka Cipta, 2008), 2.

14 Hasan Langgulung, Pendidikan Islam Dalam Abad Ke 21 (Jakarta: PT. Pustaka Al- Husna Baru, 2003), 70.

15 Nurori Soyomukti, Teori-Teori Pendidikan; Tradisional (Neo), Liberal, Marxis-Sosialis, Postmodern (Yogyakarta: Ar-Ruzz Media, 2010), 28-29. tahun dan dilaksanakan di ruang-ruang kelas. Istilah itu sering disebut masa preschool, yang diartikan sebagai periode anak yang dapat diberikan mimbingan dan pengajaran. Tetapi anggapan tersebut tidak terbukti, karena dari pandangan ajaran Islam memandang periode pendidikan untuk manusia terbagi menjadi tiga tahapan yakni periode pranatal, postnatal dan sepanjang hayat.

Mansur menjelaskan di dalam karyanya yang berjudul Mendidik Anak Sejak dalam Kandung bahwa pendidikan pranatal dapat diartikan mendidik anak sebelum kelahiran. Pendidikan pranatal dapat dipahami sebagai segala kegiatan manusia sebagai calon suami dan istri yang berkaitan dengan hal-hal sebelum kelahiran seperti sikap dalam rangka untuk menemukan atau memilih pasangan hidup dengan tujuan agar calon janin dapat terlahir dengan keadaan sehat jasmani dan rohani, sehingga potensi fitrah manusia dapat ditumbuh kembangkan secara maksimal. ${ }^{16}$ Sementara pendapat yang tidak jauh berbeda, Ubes menjelaskan bahwa pendidikan pranatal merupakan upaya sadar dari calon orang tua untuk mendidik, mengasuh dan membimbing anaknya yang masih berupa janin di dalam rahim istri. Upaya tersebut dikhususkan kepada orang tua karena anak yang ada di dalam kandungan memang belum dapat didik secara kasat mata, melainkan mendidik dengan cara khusus yang dilakukan oleh orang tuanya sendiri. ${ }^{17}$

16 Mansur, Mendidik Anak Sejak Dalam Kandungan, (Yogyakarta: Mirta Pustaka, 2006), 16.

17 Ubes Nur Islam, Mendidik Anak Dalam Kandungan, Optimalisasi Potensi Anak Sejak Dini (Jakarta: Gema Insani, 2004), 10. 
Ibu dan bapak dapat disebut sebagai orang tua yang memiliki kewajiban dalam mendidik anaknya dan tidak dapat dipisahkan dalam kehidupan untuk membimbing, mengasuh dan mengasihi janin yang diamanahkan oleh Allah. Pernyataan tersebut menandakan bahwa pendidikan merupakan upaya yang memiliki nilai luhur sekaligus keniscayaan yang dibebankan oleh Allah kepada semua orang tua untuk menanamkan keimanan, pengetahuan dan budi pekerti ke dalam lubuk hati anak-anak baik masih di dalam kandungan ataupun sudah terlahir ke dunia. Dalam konsep pendidikan Islam, pendidikan dimulai ketika asal terciptanya manusia seperti proses sperma bertemu dengan ovum dan terbentuk manusia secara utuh, alhasil pendidikan yang dimulai dari bentuk janin dapat dipahami sebagai pendidikan pranatal. Islam memandang bahwa anak merupakan amanah dan tanggung jawab orang tua, seharusnya orang tua tidak boleh mengabaikan setiap tumbuh berkembangnya anak dari masa janin pranatal hingga pascanatal, hingga sepanjang hayat dan berakhir di liang lahat. Pernyataan tersebut sesuai dengan ajaran Islam yang memandang pendidikan dimulai dari dalam kandungan hingga samapai keliang lahat.

Tri Andiyanti mengutip pendapat Saiful Bahri bahwa masa pranatal merupakan proses pertumbuhan dan perkembangan di awal kehidupan manusia. ${ }^{18} \quad$ Pertumbuhan dan perkembangan di awal kehidupan tersebut dapat diartikan dari dua aspek yaitu psikologis dan biologis. Aspek psikologis dipahami bahwa kehidupan

18 Tri Andiyanto, "Konsep Pendidikan Pranatal, Postnatal Dan Pendidikan Sepanjang Hayat," Elementary: Jurnal Ilmiah Pendidikan Dasar, Vol. 4, No. 2 (2018). manusia dimulai pada saat janin mulai bereaksi terhadap rangsanganrangsangan dari luar. Sementara ditinjau secara aspek biologis kehidupan manusia dimulai pada saat terjadinya konsepsi atau pembuahan, yakni bersatunya sperma dengan sel telur di dalam rahim. ${ }^{19}$ Herdina Indrijati menjelaskan di dalam bukunya yang berjudul Psikologi Perkembangan dan Pendidikan Anak Usia Dini bahwa hasil penelitian yang paling mutakhir tentang dunia pralahir menunjukkan bahwa rahim ibu adalah ruang kelas yaitu ruang dimana janin dapat belajar tentang banyak hal, belajar untuk mencapai perkembangan fisik dan psikis secara optimal, serta mengembangkan otak dan saraf janin sebelum dilahirkan. ${ }^{20}$ Perihal tersebut dapat dipahami bahwa pada dasarnya janin yang masih berada di dalam kandungan dapat dididik dan mampu untuk menerima didikan dari luar kandungan. Dengan demikian teori dan penjelasan tersebut dapat dimaknai bahwa proses pendidikan pranatal sangat besar pengaruhnya bagi perkembangan manusia. Berdasarkan uraian diatas, memberikan satu pertanyaan yakni bagaimana cara mendidik janin yang masih berada di dalam rahim, seringkali perempuan yang sedang hamil atau orang-orang yang berada di sekitar perempuan yang sedang hamil, tidak begitu paham bagaimana melakukan pendidikan kepada anak yang masih dalam wujud janin yang berada di dalam rahim ibunya. Mendidik anak yang masih dalam bentuk janin pada prinsipnya memberikan stimulus pada sel-sel otak pada janin, cara tersebut dilakukan bermaksud untuk memberikan

\footnotetext{
19 Rita Eka Izzaty, et.al, Perkembangan Peserta Didik (Yogyakarta: UNY Press, 2008), 53.

20 Indrijati, et.al, Psikologi Perkembangan \& Pendidikan, 3.
} 
kesempatan untuk mengaktifkan dan memanfaatkan sel-sel otak janin sebelum dilahirkan.

Mendidik anak sejak bentuk janin, sebenarnya telah berkembang dari zaman nenek moyang melalui budaya yang diterapkan dalam kehidupan sehari-hari bagi perempuan yang mengalami hamil. Yang dimaksud kebudayaan peninggalan nenek moyang seperti kaum perempuan dari negara Uganda terbiasa memijat, membelai, dan bernyanyi untuk bayi mereka pada dua hari pertama setelah kelahiran dan bayi-bayi ini terjaga lama, penuh perhatian, bahagia, tenang dan mereka hampir tidak pernah menangis. ${ }^{21}$ Berbeda halnya dengan kebudayaan dari masyarakat Bani Israil dalam mendidik anak sejak bentuk janin yang masih di dalam rahim, budaya dari perempuan Bani Israil dapat dikatakan berhasil dalam melakukan pendidikan pranatal sebab sampai sekarang Bani Israil terkenal dengan bangsa yang memiliki kecerdasan yang tinggi, anak keturunan dari mereka merupakan orang-orang cerdas dan genius. $^{22}$ Keberhasilan Bani Israil dalam mendidik anak tidak lain karena kebudayaan yang dimiliki nenek moyang mereka seperti kebiasaan mendengarkan musik secara rutin untuk perempuan yang hamil, mengajak janinnya bicara dan bersenandung. Dilihat dari konteks sejarah anak keturunan dari Bani Israil banyak melahirkan cendekiawan seperti Albert Einsten dari aspek ilmu pengetahuan dan Lionel Messi yang memiliki kecerdasan dari aspek sepakbola. Berdasarkan pandangan di atas dapat dipahami bahwa pendidikan pranatal pada janin sangat perlu diperhatikan

\footnotetext{
21 Ibid, 11.

22 Miftahul Kasana and Anggraeni Novita Sari, "Pendidikan Pranatal Yahudi Dan Relevansinya
}

oleh calon kedua orang tua, hal tersebut dapat dilihat dari masyarakat Bani Israil yang sangat memperhatikan aspek pendidikan sejak dalam kandungan, sehingga memiliki keturunan yang memiliki intelegensi dan spiritual yang cukup cerdas.

Dari hasil sebuah penelitian yang dilakukan oleh para ahli, Herdina Indrijati mengutip hasil penelitian Van de Carr dan Lehrer pada tahun 2001 menyebutkan bahwa bayi yang diberi stimulus pralahir seperti dilatih untuk mendengarkan musik dan sering diajak bicara ketika di dalam perut, maka janin akan cepat berbicara, menirukan suara, menyebutkan kata pertama, tersenyum spontan, menolehkan kepala ke arah suara orang tuanya, lebih tanggap terhadap musik dan juga mengembangkan pola sosial lebih baik di saat dewasa. Berdasarkan hasil penemuan tersebut dapat dipahami bahwa pendidikan pranatal dapat dilakukan dengan mengunakan stimulus yang dilakukan secara konsisten untuk merangsang pertumbuhan sel otak yang dapat menumbuhkan kemampuan memberi dan menerima kasih sayang. Stimulus tersebut dapat dilakukan saat usia janin mencapai lebih kurang 24 minggu, karena pada organ pendengaran janin sudah terbentuk dan berfungsi dengan sempurna.

Dengan demikian hasil pemaparan di atas dapat dipahami bahwa pendidikan pranatal semacam proses pemberian stimulus kepada janin sebagai upaya untuk mendidik dan menumbuh kembangkan potensi yang dimiliki anak sebelum dilahirkan. Pendidikan pranatal ini begitu penting karena masa pranatal menjadi pondasi

Dengan Pendidikan Islam," Academica: Journal of Multidisciplinary Studies, Vol. 1, No. 2 (2017). 
dasar dalam mengharapkan kehadiran anak yang baik secara intelegensi dan spiritual. Sementara pemaknaan khusus pranatal dapat diartikan sebagai pemeliharaan janin sedini mungkin, dengan cara mengunakan stimulus yang bersifat sentuhan dan bentuk suarasuara yang lembut serta nyaring ketika didengarkan oleh telingga manusia. Oleh karena itu, pendidikan pranatal bertujuan untuk membantu orang tua dan anggota keluarga dalam memberikan lingkungan yang lebih baik bagi janin dan memberikan peluang untuk belajar lebih dini serta mampu menciptakan dorongan interaksi yang positif bagi orang tua dan calon anak yang berbentuk janin di dalam perut. Berdasarkan penjelasan tersebut pendapat yang senada dengan hal tersebut adalah Baihaqi. ${ }^{23}$ Ia menjelaskan bahwa hakekat pendidikan pranatal dapat dilakukan dengan memberikan stimulus, cara tersebut kemudian dijadikan metode yang disusun dan diarahkan melalui proses pembinaan lingkungan secara edukatif atau bersifat Islami dari calon ibu, ayah dan untuk anggota inti keluarga yang lainnya.

\section{Perspektif Islam Tentang Pendidikan Pranatal}

Muhaimin berpendapat bahwa Islam memandang pendidikan anak dimulai jauh sebelum kelahiran anak, seperti tahap memperbaiki diri sebelum mendapatkan jodoh, pernikahan, etika berhubungan badan denga isteri, proses mengandung, kelahiran sampai akhir kayat. Mendidik anak sejak masih berbentuk janin merupakan pada hakikatnya bentuk usaha konkret dari calon orang tua dalam rangka mensyukuri karunia rezeki dan

23 Baihaqi, Mendidik Anak Dalam Kandungan (Jakarta: PT Grafindo Persada, 1996), 115.

24 Abu Abdillah Muhammad bin Abi Bakrin bin Ayyub Ibnu Qayyim Al-Jauziyyah, Tuhfah Al-Maudud mengemban amanat dari Allah, sebagai alasan paling mendasar pembentukan manusia dimulai sejak pertemuan sperma dan ovum sehingga akan terbentuk janin dan kemudian ditiupkan ruh. Dari tahapan tersebut secara Islam memberikan anjuran dan perintah agar dalam pemilihan jodoh harus berhati-hati, sebab pasangan suami istri ketika melakukan hubungan biologis akan memindahkan beberapa gen orang tua dan menularkan sifatsifat dan bentuk fisik secara umum dari orang tua kepada calon anak, ketika anak lahir tidak akan jauh dari sifat-sifat moral dan spiritual dari hasil pembawaan orang tua. Pernyataan tersebut sesuai dengan pendapat para cendekiawan Islam yang menyatakan bahwa fase pertama dalam pendidikan pranatal dimulai ketika memilih pasangan hidup, seperti halnya pendapat Ibnu Qayyim Al-Jauziyyah mengemukakan bahwa pendidikan pranatal salah satu konsep yang perlu direalisasikan melalui tahapan-tahapan yang konkret dengan memilih jodoh sebagai usaha pemilihan bibit dan bobot yang terbaik untuk diajak menikah dan menjadi pendidik dalam satu keluarga. ${ }^{24}$ Sementara Islam memandang pendidikan pranatal melalui beberapa tahapan, diantaranya tahapan-tahapan yang perlu dilakukan agar pendidikan pranatal berjalan secara sempurna yakni;

a) Tahapan Pemilihan Jodoh

Menentukan pasangan hidup dapat diartikan sebagai tahap pertama dari pendidikan pranatal yang harus dilalui sebelum memasuki tahap pernikahan. Kemudian sepasang manusia yang menikah pasti mengharapkan kehadiran buah hati

Bi Ahkami Al-Maulud, 1st ed. (Cairo: Daru Ibnu AlJauzi, 2021), 6-7. 
yang sehat dan cerdas dari aspek fisik, spiritual dan intelegensi. Tetapi tidak semua pasangan suami istri mampu menghasilkan keturunan yang cerdas secara spiritual ataupun intelegensi. Perihal tersebut membutuhkan persiapan yang cukup panjang untuk melakukan pendidikan pranatal. Tahap paling awal adalah memilih patner hidup yang memiliki kategori sebagai berikut ini, pertama segi kecantikan, kekayaan, kecerdasan dan memiliki sikap beragama yang baik, sebab pemilihan jodoh merupakan pintu pertama dalam proses pendidikan pranatal. Ketika memilih jodoh dianjurkan untuk melihat kecantikan, kekayaan, kecerdasan dan sikap beragama yang baik sebagai patokan untuk merencanakan keluarga yang berkualitas. Oleh karena itu, anak yang baik dan berkualitas pasti akan terlahir dari orang tua yang mempunyai intelegensi dan spiritual yang berkualitas pula. Upaya yang perlu dilakukan untuk mendapatkan keturunan yang berkualitas dalam pernikahan adalah paling utama memilih calon pendamping hidup yang memiliki spiritual dan agama yang baik.

Aeni Mahmudah berpendapat bahwa agama merupakan faktor utama dalam memilih pasangan hidup. ${ }^{25}$ Pernyataan ini didasarkan pada hadits riwayat $A b u$ Hurairah yang menjelaskan bahwa dalam pemilihan jodoh selain melihat kecantikan, kecerdasan, kekayaan, maka agama yang lebih diutamakan dan menjadi patokan pertama saat menentukan patner hidup. Uraian tersebut sesuai dengan firman Allah dalam surat Al-Baqarah ayat 221 sebagai berikut.

25 Aeni Mahmudah, "Memilih Pasangan Hidup Dalam Perspektif Hadits (Tinjauan Teori Dan Aplikasi)," Diyah Al-Afkar, Vol. 4, No. 1 (2016).

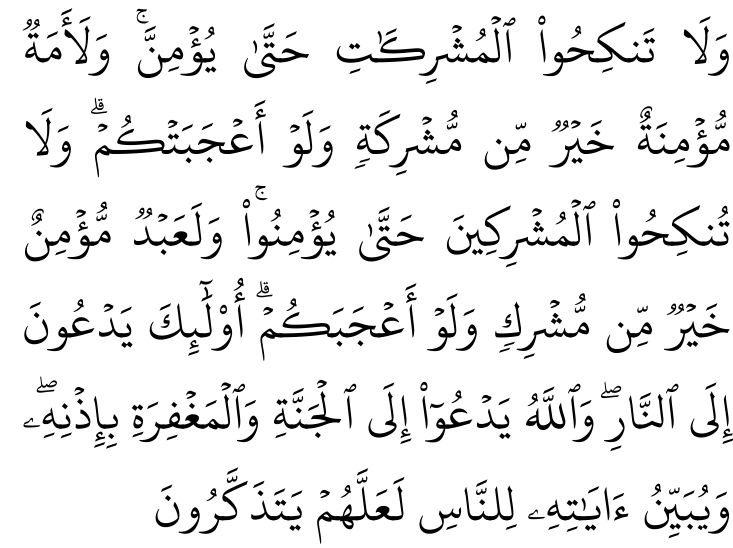

Artinya; "Dan janganlah kamu menikahi wanita-wanita musyrik, sebelum mereka beriman. Sesungguhnya wanita budak yang mukmin lebih baik dari wanita musyrik, walaupun dia menarik hatimu. Dan janganlah kamu menikahkan orang-orang musyrik dengan wanita-wanita mukmin sebelum mereka beriman. Sesunguhnya budak yang mukmin lebih baik dari orang musyrik, walaupun dia menarik hatimu. Mereka mengajak ke neraka, sedang Allah mengajak ke surga dan ampunan dengan izin-Nya. Dan Allah menerangkan ayat-ayat-Nya (perintahperintah-Nya), kepada manusia supaya mereka mengambil pelajaran". 26

M. Quraish Shihab pakar tafsir berpendapat bahwa tidak ada pondasi yang paling kuat dan kokoh selaian agama untuk melangsungkan kehidupan bersama dalam meraih kebahagian dan mendapatkan keturunan yang berkualitas. Pernyataan tersebut merujuk pada pendapat Nabi Muhammad yang memberikan pedoman kepada lelaki dan perempuan yang ingin menikah agar memilih pasangan yang taat berpegang kepada agama, karena dengan adanya agama yang tertanam sejak dari orang tua akan menghasilkan keturunan yang cerdas secara spritual. Berdasarkan uraian di

26 Departemen Agama Republik Indones, Alquran Dan Terjemahannya, Surat Al-Baqarah Ayat 221, (Jakarta: PT Restu Bumi, 1976-1977.), 53. 
atas, ternyata sesuai dengan hadits yang diriwayatkan oleh Abu Hurairah.

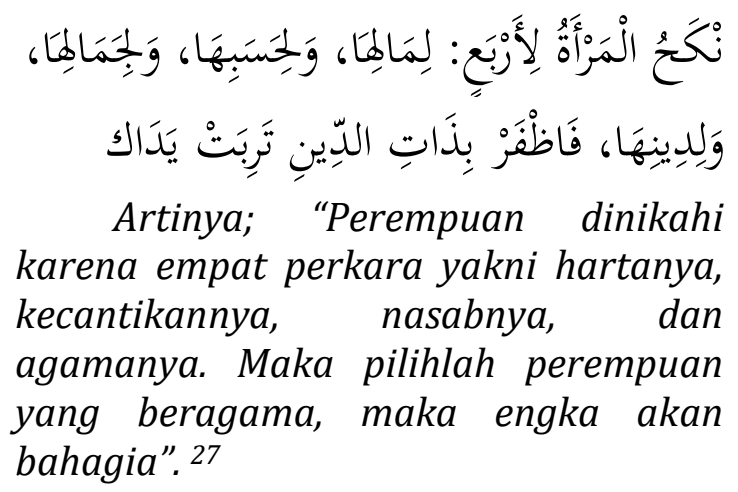
karena empat perkara yakni hartanya, kecantikannya, nasabnya, dan agamanya. Maka pilihlah perempuan yang beragama, maka engka akan bahagia". 27

Dengan demikian, berdasarkan ayat dan hadits di atas dapat dipahami bahwa perempuan dinikahi karena empat perkara dan yang paling utama adalah agamanya. Dalam Alquran dan Hadits mengisyaratkan kepada laki-laki untuk memilih perempuan yang memiliki spiritual yang baik yang berpatokan agama sebagai dasar, perempuan yang memiliki spiritual yang baik diibaratkan sebagai lahan paling subur untuk menciptakan generasi yang bertaqwa dan cerdas dari segi spiritual. Sebagaimana kisah yang terdapat di dalam ajaran Islam, ada beberapa perempuan yang memiliki spiritual yang baik seperti Hanna istri Imran dan Maryam binti Imran. Mereka perempuan-perempuan yang memiliki spiritual yang baik, sehingga mereka mampu melahirkan anak-anak yang sholeh-sholehah. Hanna istri Imran melahirkan putri yang bernama Maryam, yang sekaligus menjadi perempuan paling mulia di mata Allah, dengan pertanda bahwa Maryam binti Imran diberi kesempatan untuk mengandung Nabi Isa tanpa melalui hubungan biologis selayaknya perempuan-perempuan lain. Maryam binti Imran melahirkan putra bernama Isa, yang sekaligus menjadi seorang

27 Mursid, Kurikulum Dan Pendidikan Anak Usia Dini (Semarang: AKFI Media, 2010), 72. nabi dan pemimpin dari kaum Bani Israil.

b) Tahapan Hubungan Biologis

Perempuan dan laki-laki yang memiliki kuffu yang sepadan secara spiritual dan memilih untuk menikah dan menentukan untuk hidup bersama dengan tujuan untuk menciptakan generasi yang berhati lembut dan terhindar dari gangguan-gangguan setan ataupun jin yang mampu merusak generasi manusia. Maka diharapkan sebelum melakukan hubungan biologis untuk mentaati etika-etika yang diajarkan, seperti membersihkan diri dengan air wudhu dan memakai wewangian, sholat sunnah 2 rakaat terlebih dahulu, sempatkan untuk berdzikir dan berdoa kepada Allah agar diberikan keturunan yang sholehsholehah, bercumbu dan bermesramesraan dengan pasangan di tempat yang bersih sekaligus terhormat, kemudian membaca doa untuk melakukan hubungan biologis supaya ketika berhubungan badan setan ataupun jin, dihilangkan dari ujung alat kelamin laki-laki, dengan artian bahwa dihilangkan agar setan dan jin tidak ikut serta dalam aktivitas seksual dan menikmati badan serta kelamin dari perempuan yang berhubungan badan dengan pasangan yang halal, sehingga sifat dasar setan seperti pemarah, pendendam, licik, tukang pemberontak tidak akan ikut masuk melalui alat kelamin dari perempuan-perempuan yang melakukan hubungan biologis dengan suaminya. Berdasarkan pernyataan tersebut Nabi Muhammad memberikan bimbingan dan pengajaran kepada kaum muslim khususnya lakilaki sebagai pemimpin keluarga agar melakukan suatu perbuatan harus didasarkan dengan berdoa terlebih 
dahulu, agar dapat menghasilkan kemaslahatan di masa yang akan datang, dengan terciptanya generasi anak manusia yang berkarakter sholehsholehah dan jauh dari sifat-sifat setan. Adapun doa yang dimaksud oleh $\mathrm{Nabi}$ Muhammad seperti dalam hadits di bawah ini.

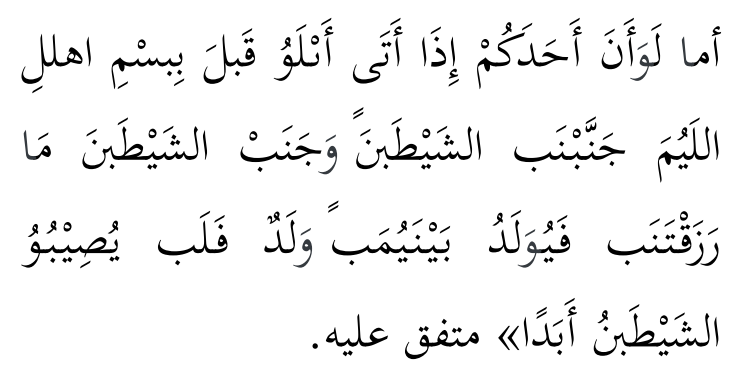

Artinya; Manakala seseorang diantara kalian sebelum mengauli istrinya terlebih dahulu mengucapkan "Dengan menyebut nama Allah, hindarkanlah kami dari gangguan setan dan hindarkan pula anak yang akan Engkau anugerahkan kepada kami dari gangguan setan, kemudian lahirkanlah dari keduanya seorang anak, niscaya selamanya setan tidak akan mengganggunya".28

Berdasarkan uraian dan hadits di atas, mengandung pemahaman bahwa seyogyanya perempuan dan laki-laki yang terikat dengan tali pernikahan diharapkan dalam melakukan kehendak atau hubungan biologis diawali menyebut nama Allah sebagai tujuan bahwa segala aktivitas seksual diniatkan hanya untuk mengabdi pada Tuhan dan pasrah diri dengan segala upaya hanya kepada Allah. Dengan begitu, segala etika telah dilaksanakan dan sesuai dengan ajaran Islam, dengan izin Allah nantinya akan tercipta anak keturunan yang bertaqwa pada Allah dan memiliki hati lemah lembut dan berkarakter sholeh sosial seperti

28 Ibnu Hajar AL-Asqalani, Bulughul Marom (Semarang: Toha Putra, 1996), 230. terciptanya sifat sabar, pemaaf serta saling sayang antar sesama manusia dan tidak akan mudah diganngu setan selama hidupnya.

c) Tahapan Ibadah

Perempuan yang telah melakukan hubungan biologis dengan suaminya, maka sperma akan bertemu dengan ovum sehingga perempuan tersebut secara ilmu biologi akan mengalami kehamilan. Ketika menghadapi masa kehamilan calon ibu diharapakan senantiasa meningkatkan amalanamalan ibadahnya seperti memperbanyak berdzikir, melaksanakan sholat hajat dan berdoa kepada Allah. Pelaksanaan ibadah bagi perempuan hamil, seyogyanya disesuaikan dengan tingkat perkembangan anak dalam kandungan, sementara dalam periode ini dalam menyesuaiakn perkembangan anak yang masih bentuk janin ada tiga periode, diantaranya sebagai berikut ini; pertama dan kedua periode pembentukan zigot dan pembentukan embrio artinya pada periode tersebut perempuan hamil diharapkan umtuk melakaukan sholat hajat dan dzikir secara istiqomah serta dihubungkan dengan doa-doa tertentu. Tahapan ibadah bagi perempuan hamil memiliki keuntungan yang begitu baik untuk janin dan ibunya. Kegiatan sholat hajat dan dzikir dapat membantu dalam pengenalan pada Tuhan, dengan artian bahwa apabila ibu melakukan ibadah, sudah melibatkan anak yang masih berada di dalam kandungan untuk terus menerus beribadah kepada Allah. ${ }^{29}$ Ketika kebiasaan ini dapat dilakukan secara istiqomah maka Allah menjadikan ibu dan janin tersebut akan senantiasa dijaga oleh Allah, selain itu

29 Rohman Nur Ichromi, "Konsep Pendidikan Pranatal Menurut Dr. Mansur, M.A Dan Ubes Nur Islam" (Malang: UIN Maulana Malik Ibrahim, 2016). 
juga akan mendapatkan ketenangan batin seperti kebahagian di dunia maupun di akhirat serta akan selalu diliputi dengan kebaikan di setiap langkah. Periode selanjutnya adalah periode ketiga yakni fetus. Yang dimaksud fetus merupakan sebutan janin yang belum lahir dari minggu ke- 8 setelah adanya pembuahan hingga saat kelahiran. Periode fetus dapat dikatakan masa paling konkret, dengan artian bahwa semua kegiatan ibadah calon ibu secara tidak langsung menghubungkan diri dengan janin yang masih berada di dalam kandungan, seperti aktivitas perempuan hamil yang akan melaksanakan sholat, kemudian perempuan hamil tersebut melakukan komunikasi searah dengan berkata "heyy... anakku yang pintar, ibuk mau melaksanakan sholat, mari kita sholat bareng yaa". Dengan suara lemah lembut dan diiringi rangsangan yang berupa usapan-usapan lembut di sekitar area perut.

\section{d) Tahapan Makanan Bergizi}

Perempuan hamil membutuhkan asupana makanan yang memiliki gizi yang cukup, dengan tujuan sebagai asupan yang diserap janin agar dapat tumbuh perkembang secara baik dari aspek fisik ataupun psikologi, karena itu perempuan hamil membutuhkan asupan gizi yang beragam untuk mencukupi zat gizi yang terkandung dalam makanan tersebut. Selain makanan yang mengandung asupan gizi yang baik, cara mendapatkan makanan tersebut juga harus yang halal dan thayyib dan berasal dari rizki yang halal. Pengertian makanan yang halal ialah semua makanan yang disediakan Allah, kecuali yang diharamkan seperti daging babi, bangkai atau hewan yang disembelih tanpa menyebutkan nama Allah. Uraian tersebut sesuai dengan firman Allah dalam surat Al-An'am ayat 145 sebagai berikut:

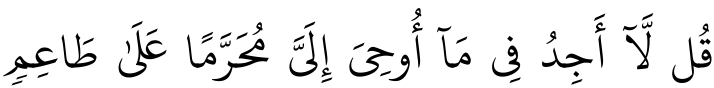

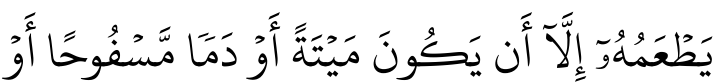

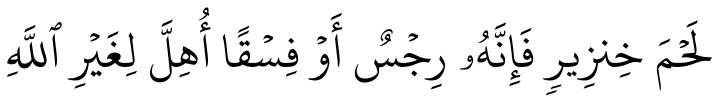

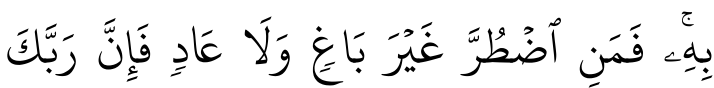

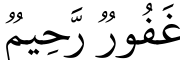

Artinya; "Katakanlah tiadalah aku peroleh dalam wahyu yang diwahyukan kepada, sesuatu yang diharamkan bagi orang yang hendak memakanya, kecuali kalau makanan itu bangkai, atau darah yang mengalir atau daging babi, karena sesungguhnya semua itu kotor, atau binatang yang disembelih atas nama selain Allah. Barangsiapa yang dalam keadaan terpaksa, sedangkan ia tidak menginginkannya dan tidak pula melampui batas, maka sesunggunya Tuhanmu Maha Pengampun lagi Maha Penyayang".30

Dengan demikian pada dasarnya perempuan hamil membutuhkan makanan yang halal dan mengandung tanbahan zat gizi untuk tumbuh kembang janin. Asupan gizi yang dimaksud adalah protein, mineral, zat besi, dan kalsium. Rata-rata kebutuhan energi yang harus dipenuhi perempuan hamil kisaran 80.000 kalori selama kehamilan. Sebagaimana contoh asupan gizi yang sangat dibutuhkan perempuan hamil seperti energi zat besi untuk pembentukan janin dan sel-sel darah merah, perkembangan otak, pembentukan otot. Apabila asupan zat besi tidak disediakan secara sempurna,

${ }^{30}$ Departemen Agama Republik Indones, Alquran Dan Terjemahannya, Surat Al-An'am Ayat 145 (Jakarta: PT Restu Bumi, 1976-1977), 212. 
perempuan hamil akan mengalami anemia sehingga menyebabkan bayi kemungkinan akan terlahir secara prematur. Adapun sumber makanan yang memiliki asupan zat besi yang rumayan tinggi diantaranya daging merah, kerang-kerangan, ikan, hati, sereal yang diperkaya dengan zat besi, kacang kedelai, kurma dan bayam. Alhasil dari uraian tersebut dapat diambil kesimpulan bahwa perempuan hamil untuk merawat tumbuh perkembangan janin sangat membutuhkan asupan gizi yang cukuk baik, untuk kebaikan dan keselamatan calon ibu dan janin, apabila dalam masa kehamilan asupan gizi tidak tercukupi bagi perempuan hamil dikuatirkan calon anak akan terlahir tidak sempurna secara fisik, intelegensi dan psikis.

\section{Kisah Maryam Binti Imran}

Maryam Binti Imran dilahirkan dari pasangan suami istri yang bernama Ali Imran dan Hannah Binti Faquds. Kedua orang tua Maryam adalah pemimpin Bani Israil yang sholeh dan sholehah serta disegani. Sementara Hannah Binti Faquds merupakan seorang perempuan yang bertekad baja dalam memberikan pengabdian terbaik kepada Allah dan mempunyai harapan untuk memiliki keturunan anak yang sholeh dan sholehah agar dapat meneruskan perjuangan orang tuanya dalam mengabdi secara totalitas kepada Allah. ${ }^{31}$ Alhasil meskipun dalam jangka waktu yang lama hingga usia tidak lagi subur untuk mendapatkan keturunan, ia tetap percaya dan memasrahkan diri kepada Allah, dengan kemukjizatan Hannah Binti Faquds yang telah berusia senja mampu mengalami siklus menstruasi dan suaminya diperintahkan untuk mendekati

\footnotetext{
31 Maria Ulfa, "Metode Pertahanan Diri Bagi Perempuan Dan Hikmah Edukasi Dalam Kisah Maryam Binti Imran" Vol. 29, No. 2 (2017): 139-149.
}

istrinya, kemudian Hannah Binti Faquds hamil dan melahirkan anak perempuan yang sholehah sekaligus perempuan yang paling mulia dan satu-satunya perempuan yang namanya diabadikan di dalam Alquran yakni Maryam Binti Imran.

Maryam Binti Imran dibesarkan oleh Nabi Zakaria, karena Ali Imran telah meninggal dunia, sementara Hannah Binti Faquds sudah tidak mampu untuk merawat Maryam Binti Imran yang dikarenakan usianya sudah tidak lagi muda. Kemudian Nabi Zakaria yang merawat dan mendidiknya. Maryam Binti Imran selama dirawat oleh Nabi Zakaria telah banyak menampakkan karamah tiada banding seperti ketika di tempat ibadah sendirian tiba-tiba buah-buahan turun dari langit. ${ }^{32}$ Karamah tersebut diberikan Allah karena Maryam Binti Imran memiliki sikap untuk bertaqarrub kepada Allah. Taqarrub yang dimaksud merupakan kegiatan yang dilakukan Maryam Binti Imran secara istiqomah dalam melakukan ibadah, kezuhudan, kemulian dan kesucian dari kotoran dan bisikan setan.

Allah memberikan asuhan Maryam Binti Imran kepada Nabi Zakaria untuk menjamin keselamatan dan pertumbuh kembang secara rohani dan jasmani, sebab Nabi Zakaria bukan orang asing bagi Maryam Binti Imran dalam hal ini menurut silsilah keturunan Nabi Zakaria adalah paman dari Maryam Binti Imran yang samasama memiliki sikap sholeh, sehingga kesholehan yang dimiliki dapat berpengaruh kepada pertumbuh kembang pada anak. Pernyataan di atas

32 Mizan Adiliah Binti Masrom, "Sosok Maryam Dalam Al-Quran (Studi Komparatif Antara Tafsir Ibnu Katsir Dan Tafsir Al-Misbah)," At-Tibyan Vol. 1, No. 1 (2019): 1-18. 
sesuia dengan firman Allah dalam Surat Ali Imran Ayat 37,

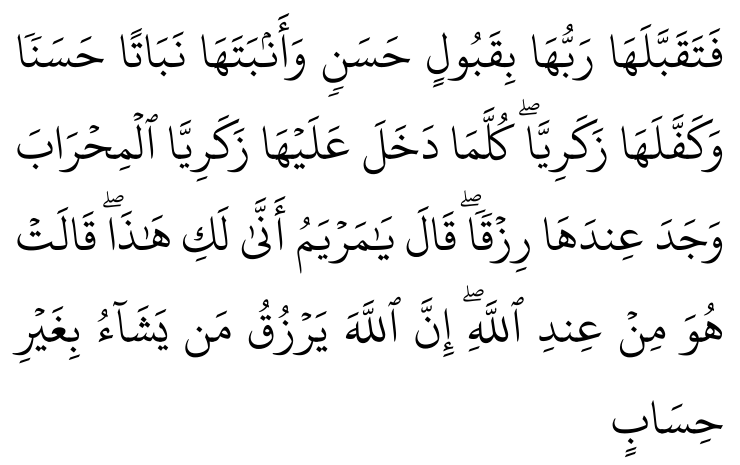

Artinya, Maka Allah menerima nazdar dengan penerimaan yang baik, membesarkannya dengan pertumbuhan baik dan menyerahkan pemeliharaannya kepada Zakaria. ${ }^{33}$

Maryam Binti Imran adalah perempuan yang sholehah, sikap tersebut sesuai dengan ibu, bapak dan pamannya yang sama-sama dari golongan orang sholeh dan sholehah. Kemudian Allah memilih Maryam Binti Imran untuk mengandung seorang Nabi Isa yang akan dilahirkan dari rahimnya, karena ibadahnya dan pengabdiannya kepada Allah yang dilakukan secara totalitas. Alhasil Maryam Binti Imran menjadi ibu dari Nabi Isa yang tercipta tanpa hubungan biologis. Putra dari Maryam Binti Imran yang bernama Isa menjadi seorang Nabi sekaligus memiliki sikap yang cerdas dan sholeh di lingkungan Bani Israil. Dengan demikian secara tersirat dapat dipahami perempuan yang memiliki ketaqwaan dan bersikap sholehah maka keturunannya akan memiliki sikap yang sama seperti ibunya yaitu baik secara spiritual.

33 Departemen Agama Republik Indonesia, Alquran Dan Terjemahannya, Surat Ali Imran Ayat 37 (Jakarta: PT Restu Bumi, 1976-1977), 81.

\section{METODE PENELITIAN}

Metode penelitian yang digunakan dalam penulisan artikel ini adalah telah pustaka atau dalam istilah lain research library. Teknis dalam metode telaah pustaka meliputi pengindetifikasian secara sistematis, analisis dokumendokumen yang memuat informasi yang berkaitan dengan masalah kajian yang melalui beberapa literatur yang sudah tersedia. ${ }^{34}$ Penelitian pustaka dapat diartikan sebagai aktivitas membac, mencatat serta menganalis dan mengolah bahan penelitian. Sementara penelitian pustaka memiliki empat ciri utama dianataranya sebagai berikut, pertama penulis harus mengumpulkan bahan literatur, sehingga penulis berhadapan langsung dengan teks-teks dan tidak perlu mengunakan pengetahuan eksklusif yang berasal dari lapangan ataupun analisis yang berupa angka-angka. Kedua data yang ditemukan dalam beberapa literatur bersifat "siap pakai" dengan artian bahwa data sudah tersedia di dalam kumpulan naskah-naskah, sehingga penulis tidak perlu melakukan pengambilan data ke lapanagan, sebab penulis berhadapan langsung dengan data-data yang terdapat di perpustakaan. Ketiga data yang berasal dari pustaka pada umumnya bersifat sekunder, dengan artian bahwa penulis mendapatkan bahan atau data berasal tangan kedua serta bukan data orisinil dari data pertama pada lapangan. Keempat bahwa syarat data pustaka tidak dibatasi dengan ruang dan waktu. Berdasarkan uraian tersebut, maka pengumpulan data pada penelitian dilakukan dengan mempelajari dan mengekplorasi jurnal, kitab, serta dokumen-dokumen (baik yang berbentuk cetak dan elektronik yang

34 Mustika Zed, Metode Penelitian Kepustakaan (Jakarta: Yayasan Obor Indonesia, 2003), 3. 
tersedia di media internet), serta sumber-sumber data dan info lainya yang dianggap relevan dengan penelitian yang sedang dikaji.

\section{HASIL DAN PEMBAHASAN}

Pendidikan pranatal yang di kisahkan dalam kisah Maryam dapat dipahami bahwa dalam penelitian ini Maryam binti Imran dalam melakukan pendidikan pranatal terbagi menjadi dua golongan yakni secara psikis dan fisik, yang sesuai dengan potensi yang dimiliki manusia yakni psikis dan fisik. Adapun lebih jelasnya akan diuraikan seperti di bawah ini.

\section{Pendidikan Pranatal Secara Psikis dari Kisah Maryam Binti Imran}

a) Tahapan Beribadah

Beribadah semacam kewajiban bagi manusia yang memiliki agama. Perintah ibadah dibawakan oleh para utusan untuk disampaikan kepada kaumnya agar mau melakukan beribadah yang disandarkan kepada Allah. Yang dimaksud ibadah ialah kegiatan untuk menyembah atau berpasrah diri kepada Allah. Menurut istilah ibadah dapat dipahami sebagai pengabdian dan kerendahan diri kepada sang pencipta alam semesta. Tujuan manusia melakukan ibadah untuk mengapai ketenangan batin secara psikis. Manusia tanpa melakukan ibadah keadan psikis akan mudah mengalami penyakit jiwa, yang membuat batin tidak tenang, resah dan cemas. Rasa kuatir dan cemas juga pernah dialami Maryam binti Imran ketika hamil Nabi Isa masih berada dalam kandungan. Kondisi yang dialami Maryam bin Imran menurut Dali Gulo

35 Muhammad Shodiq Masrur and Azka Salsabila, "Peran Agama Dalam Kesehatan Mental (Kajian Psikologis Atas Kisah Maryam Binti Imran Dalam QS Maryam: 18-22)," Jurnal Akademika, Vol. 14, No. 2 (2020). merupakan gejala neurosis yang ditandai rasa cemas yang kronis. ${ }^{35}$ Sementara pandangan ilmu medis gejala neorosis sangat beresiko buruk bagi tumbuh kembang janin secara psikologis dan spiritual. Meskipun demikian Maryam binti Imran ialah perempuan mulia yang dikasihi dan diberi pertolongan oleh Allah dalam keadaan neorosis ia diperintahkan untuk melakukan ibadah dalam bentuk selalu mengingat kepada Allah. Maryam binti Imran telah membuktikan bahwa selama kehamilan sering mendekatkan diri kepada Allah dengan cara melakukan ibadah. Alhasil bayi yang dilahirkan memiliki kecerdasan secara spiritual dan ketika tumbuh dewasa bayi tersebut memiliki mental yang tangguh dan tidak mudah mengalami depresi meskipun mengalami tekanan dan cobaan hidup yang berat. Pernyataan ini diabadikan di dalam Alquran dari Surat Maryam Ayat 18.

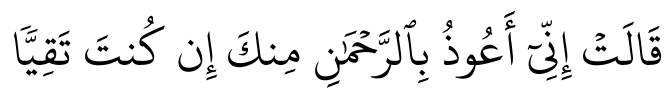

Artinya; Maryam berkata, sesungguhnya aku berlindung dari padamu kepada Tuhan yang Maha Pemurah, Jika kamu seorang yang bertakwa. ${ }^{36}$

Firman Allah tersebut menjelaskan bahwa Maryam binti Imran ketika kedatangan malaikat Jibril berbentuk seseorang laki-laki dan seorang laki-laki tersebut sebelum meniupkan ruh anak laki-laki yang suci ke dalam rahim. Maryam binti Imran berdoa meminta perlindungan untuk dirinya dan anak keturunannya agar tetap bertakwa kepada Allah. Terkait yang dilakukan Maryam binti Imran

\footnotetext{
36 Departemen Agama Republik Indones, Alquran Dan Terjemahannya, Surat Maryam Ayat 18 (Jakarta: PT Restu Bumi, 1976-1977), 464.
} 
memiliki tujuan bahwa selama proses pembuahan dan kehamilan pada umumnya mempengaruhi intensitas emosi dan tekanan batin pada psikis perempuan hamil. Dalam kasus yang dialami Maryam binti Imran bahwa peran agama sangat dibutuhkan untuk menghilangkan tekanan batin yang berupa stress, hal ini sesuai pendapat shodiq masrur bahwa Maryam binti Imran mencari solusi penyelesaian dengan mendekatkan diri kepada Allah melalui agama dengan cara sholat/berdoa, berdzikir dan berpuasa di tempat yang sepi dan jauh dari lingkungan sosial. ${ }^{37}$ Pernyataan tersebut sesuai dengan penjelasan Syaiful hamali bahwa manusia memiliki kebutuhan yang paling mendasar terkait nilai metafisis dan norma keagamaan untuk menyembuhkan kegelisahan dan menciptakan ketenangan serta menghilangkan rasa stress. Begitu juga dengan perempuan hamil di masa sekarang harus lebih sering melakukan ibadah seperti berdoa dan berdzikir kepada Allah, sebab perubahan yang terjadi pada fisik dan psikologis perempuan hamil menyebabkan kecemasan atau rasa ketakutan yang dapat mempengaruhi tumbuh kembang pada janin yang berada dalam rahim. Tahapan ibadah pada perempuan hamil dapat dijadikan sebagai bahan terapi untuk menurunkan kecemasan, yang dilakukan dengan cara mengingat yang berupa tindakan dan ucapan akan keberadaan Allah. Apabila perempuan hamil sering mengalami kecemasan, rasa takut dan rasa sedih akan berpengaruh buruk pada tumbuh kembang janin secara psikis. Dampak

37 Muhammad Shodiq Masrur and Azka Salsabila, "Peran Agama Dalam Kesehatan Mental (Kajian Psikologis Atas Kisah Maryam Binti Imran Dalam QS Maryam: 18-22)." Jurnal Akademika, Vol. 14, No. 2 (2020). itu bila dibiarkan kelak di masa dewasa ataupun ketika janin sudah lahir akan membuat bayi sering rewel, mudah marah dan rentan depresi, sehingga dapat dikatakan janin tersebut tidak cerdas secara spiritual.

Merujuk dari penjelasan dan ayat di atas dapat dimaknai bahwa kegiatan ibadah memiliki manfaat bagi perempuan hamil seperti kesehatan mental dan fisik bagi perempuan hamil dan perkembangan janin selama masih berada di dalam kandungan. Sejumlah penelitian yang dilakukan menyatakan bahwa kegiatan ibadah seperti gerakan sholat diantaranya berdiri, ruku' sujud dan duduk dapat disamakan dengan jenis olahraga, sebab itu gerakan sholat dapat memberikan manfaat untuk kesehatan. Selain itu juga beribadah memiliki beberapa manfaat untuk perempuan hamil dan kesehatan janin. Pernyataan tersebut dibuktikan dalam penelitian yang dilakukan Columbia Universitas State, hasil penelitian menyatakan bahwa dalam kegiatan ibadah seperti gerakan sholat seperti sujud dapat mengaliri bagian otak yang tidak teraliri darah. Bgaian tersebut dapat disebut Prefrontal Cortex yang berfungsi dalam pengambilan keputuasanatau dalam memilih keputusan. ${ }^{38}$ Apabila perempuan hamil memiliki kecerdasan dalam bentuk meningkatnya intelegensi tentunya akan berdampak pada kecerdasan janin yang berada di dalam kandungan. Oleh karena itulah apabila perempuan hamil sering melakukan kegiatan ibadah dapat membentuk dan meumbuh kembangkan kecerdasan bagi janin.

38 Fadhila Auliya Widia Putri, dalam https://id.theasianparent.com/manfaat-sholatuntuk-ibu-hamil /post/read/11 Manfaat Sholat Untuk Ibu Hamil Yang Jarang Diketahui Banyak Orang, 2021. 


\section{Pendidikan Pranatal Secara Fisik dari Kisah Maryam Binti Imran}

a) Tahapan Pemilihan Jodoh

Maryam binti Imran merupakan sosok perempuan yang taat beragama, sholehah dan beriman kepada Allah. Maryam dilahirkan dari pasangan suami istri yang bernama Ali Imran bin Matsan dan Hanna binti Faqudha. Mereka berdua ialah orang alim sekaligus golongan ulama' di kalangan Bani Israil. Sementara ibu kandung Maryam dikenal sebagai perempuan yang sholehah. Pernyataan tersebut sesuai dengan firman Allah yang dijelaskan dalam Alquran dari Surat Ali Imran ayat 33.

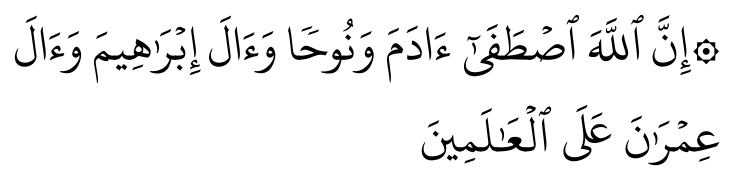

Artinya; "Sesungguhnya Allah telah memilih Adam, Nuh, keluarga Ibrahim dan keluarga Imran melebihi segala umat (di masa mereka masingmasing)"39

Merujuk kepada kisah yang terdapat dalam Alquran, Ali Imran bin Matsan dan Hanna binti Faqudha, memiliki keturunan yang sholehah karena mereka melakukan proses pendidikan pranatal secara baik, seperti dalam memilih pasangan hidup yang memiliki kaffah artinya sepadan. Yang dimaksud kaffah merupakan sepadan dalam hal agama, nasab, status kemerdekaan, pekerjaan dan harta. Sementara yang dikisahkan dalam kisah Maryam binti Imran, kedua oarng tuanya sama-sama termasuk golongan orang-orang alim, dan selalu berdoa untuk berkomunikasi langsung secara vertikal kepada Allah agar diberikan keturunan yang sholeh-sholehah

${ }^{39}$ Departemen Agama Republik Indones, Alquran Dan Terjemahannya, Surat Ali Imran Ayat 33 (Jakarta: PT Restu Bumi, 1976-1977), 80. sebagai generasi penerus perjuangan mereka. Meskipun mereka berdua tidak secara langsung mendapatkan keturunan melainkan mereka dicoba terlebih dahulu dengan Hanna binti Faqudha yang susah untuk hamil hingga usia tidak cukup muda, tetapi mereka sabar dan tetap beriman. Uraian tersebut sesuai dengan penjelasan yang terdapat dalam Alquran dari surat Ali Imran ayat 35 .

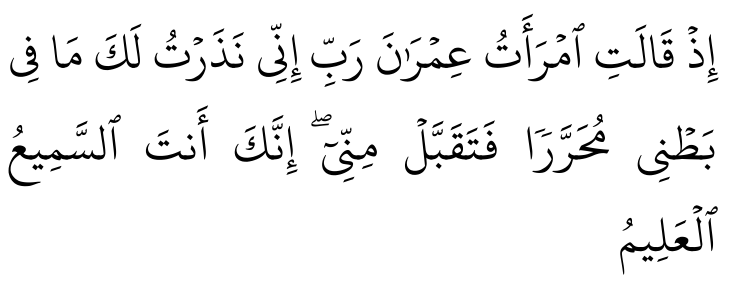

Artinya; Ingatlah, ketika isteri Imran berkata $Y a \quad$ Tuhanku, sesungguhnya aku bernazaar kepada Engkau anak yang dalam kandunganku menjadi hamba yang shaleh dan berkhidmat (di Baitul Maqdis). Karena itu terimalah nazar itu dari padaku. Sesungguhnya Engkaulah yang Maha Mendengar lagi Maha Mengetahui."

Menurut pakar tafsir M. Quraisy Shihab Allah mengabulkan doa dan harapan Hanna binti Faqudha, alhasil ia mengalami haid dan ketika suci dari haid, suaminya mendatangi dan yakin akan diberikan sebuah keturunan yang taat kepada Allah. Harapan yang diperlihatkan Hanna binti Faqudha termasuk bentuk nazar kepada Allah. Dalam konteks ucapan nazar istri imran adalah tekad dan berjanji untuk menjadikan anak yang dikandunganya berkhidmat secara penuh di Baitul AlMaqdis. Dengan ketulusan doa yang dilantunkan secara terus menerus dan disandarkan kepada keyakinan. Hanna binti Faqudha mendapatkan keturunan yang alim dan taat beragama dalam

40 Departemen Agama Republik Indones, Alquran Dan Terjemahannya, Surat Ali Imran Ayat 35 (Jakarta: PT Restu Bumi, 1976-1977), 81. 
bentuk berkhidmat di Baitul Maqdis. Hal tersebut sesuai dengan harapan dan doa dari kedua orang tuanya, sehingga Maryam binti Imran tumbuh menjadi perempuan yang sholehah dan menjadi satu-satunya perempuan yang paling mulia.

Berdasarkan pengalan uraian di atas, dapat dipahami bahwa Maryam binti Imran dapat tumbuh menjadi perempuan yang sholehah dan menjadi perempuan yang paling mulia serta namanya diabadikan di dalam Alquran, karena hasil dari kealiman kedua orang tuanya yang sama-sama memiliki sikap yang taat beragama. Allah memandang Maryam binti Imran karena memiliki kecerdasan secara spiritual yang tidak lain karena usaha orang tuanya yang sebelum menikah mempersiapkan atau memperbaiki sikap spiritual agar lebih sepadan dengan pasangan dan memilih pasangan yang memiliki keimanan yang totalitas, selain itu sebelum berhubungan biologis dengan suami, Hanna binti Faqudha berusaha memperbaiki diri dengan selalu menanamkan rasa iman, melaksanakan segala perintah, menjauhi segala larangan serta berdoa tanpa putus untuk mengharapkan kebaikan dan kemulian. Dengan demikian, dari kisah tersebut dapat dipahami bahwa konsep pendidikan pranatal yang dilakukan Hanna binti Faqudha dimulai dari tahap pemilihan jodoh yang memiliki keimanan dan ketaatan kepada Allah, hal itu sesuai dengan pemikiran Ibnu Qayyim Al-Jauziyah bahwa pendidikan pranatal dimulai dari menentukan pasangan hidup, akan tetapi kecantikan atau ketampanan, kaya harta, dan status sosial yang dihormati masyarakat bukanlah merupakan pilihan utama dalam mencari pasangan hidup, sebab nantinya dalam proses pendidikan pranatal pada janin bukan dimulai dari paras yang cantik atau tampan, harta kekayaan dan status sosial, tetapi orang tua yang akan mendidik anak dengan agama, seperti perempuan dan laki-laki harus memiliki ketaatan dalam beragama serta perempuan yang berasal dari keluarga yang baik yang dilihat dari segi akhlaknya. Kriteria tersebut dijadikan yang paling utama dikarenakan sifat-sifat, kecerdasasan spiritual, intelegensi dan tingkah lakunya akan menurun atau diwariskan kepada anak-anaknya yang akan dilahirkan, seperti yang diterapkan Hanna binti Fuqadha, yang sholehah dan alim melahirkan keturunan berupa Maryam binti Imran yang selalu berkhidmat di Baitul Maqdis. Jadi wajar saja, apabila Maryam binti Imran memiliki sifat-sifat dan kecerdasan spiritual yang mampu melanjutkan perjuangan orang tuanya yang berkhidmat secara totalitas kepada Allah. Begitupun dengan Maryam binti Imran yang selalu menjaga diri, beribadah dan setiap saat berkhidmat hanya kepada Allah di Baitul Maqdis. Alhasil Maryam juga diberikan keturunan yang sholeh, taat beragama sekaligus menjadi seorang Nabi dari Bani Israil

b) Tahapan Hubungan Biologis

Kegiatan seks yang sering disebut sebagai hubungan biologis pasti berkaitan dengan alat kelamin dengan tujuan untuk mencapai kenikmatan. Semua makhluk hidup khususnya manusia juga memerlukan kegiatan seks sebagai kebutuhan dalam menjalani kehidupan. Tidak dapat dipungkiri bahwa hubungan biologis sebagian besar dilakukan karena dorongan birahi, sehingga seringkali sebagian manusia melupakan etika hubungan biologis. Alhasil tidak ada bedanya dengan hewan yang melakukan hubungan biologis. Etika hubungan biologis memiliki peran penting dalam menciptakan manusia 
yang memiliki kecerdasan spiritual. Hubungan biologis merupakan hal mutlak dan salah satu bentuk ibadah dalam Islam. Etika hubungan biologis tersebut diatur agar tidak mengurangi keberkahan dan membuat masingmasing pasangan merasa nyaman dan dicintai. Sementara menurut Muhammad Al-Tahami bin Madani berpendapat dalam kitabnya yang berjudul Qurratul Uyyun bahwa kaum muslimin diharapkan untuk memperhatikan etika-etika dalam hubungan biologis agar memiliki perbedaan yang dilakukan oleh hewan. Adapun etika hubungan biologis yang terangkum dalam kitab tersebut salah satunya adalah berdoa sebelum melakukan hubungan biologis kepada pasangan halalnya.

Hanna binti Fuqadha juga berdoa sebelum melakukan hubungan biologis. Pernyataan tersebut dapat dilihat dari Alquran dalam Surat Ali Imran bahwa dikisahkan Hanna binti Fuqadha berdoa dibawah pohon dan melihat beberapa burung yang memberikan makan anaknya, kemudian tergerak hatinya Hanna binti Fuqadha untuk berdoa kepada Allah agar diberikan anak lakilaki dan Allah menerima doa tersebut dan seketika itu pula Hanna binti Fuqadha mengalami haid kembali meskipun usianya sudah tidak muda lagi. Kemudian setelah Hanna binti Fuqadha suci dari haid, suaminya mendatanginya untuk melakukan hubungan biologis dan yakin akan diberikan seorang anak laki-laki. Maryam binti Imran juga sama berdoa terlebih dahulu sebelum ruh dari nabi Isa ditiupkan ke dalam rahimnya. Meskipun proses kehamilan Maryam binti Imran tidak melalui hubungan biologis selayaknya perempuan lain, akan tetapi Maryam binti Imran tetap mengingat dan meminta perlindungan kepada Allah, ketika kedatangan sosok laki-laki yang merupakan malaikat Jibril sekaligus memberikan kabar bahwa ruh nabi Isa akan ditiupkan ke dalam rahimnya. Berdasarkan uraian tersebut M. Quraisy Shihab menjelaskan juga bahwa Maryam binti Imran meminta perlindungan dan pertolongan kepada Allah melalui berdoa, sebelum ruh tersebut ditiupkan ke dalam badannya. Adapun pernyataan tersebut dapat dilihat dalam Alquran dari Surat Maryam Ayat 18.41

Merujuk pada uraian di atas, dapat dimaknai bahwa proses pendidikan pranatal yang dilakukan oleh Hanna binti Fuqadha dan Maryam binti Imran adalah berdoa terlebih dahulu sebelum ruh ditiupkan ke dalam rahim. Meskipun Maryam binti Imran dalam proses kehamilan tidak melewati hubungan biologis, akan tetapi sebelum malaikat Jibril meniupkan ruh ke rahimnya, Maryam binti Imran berdoa untuk meminta perlindungan kepada Allah. Berdasarkan dari penggalan kisah tersebut, dapat dipahami bahwa Islam mengajarkan kepada pemeluknya untuk selalu berdoa, begitupun dengan para orang-orang alim yang dikisahkan di atas seperti Hanna binti Fuqadha dan Maryam binti Imran akan tetap berdoa dalam kegiatan apapun. Tidak jauh berbeda dengan ajaran Islam yang dibawakan oleh Nabi Muhammad yang banyak memberikan contoh dalam berdoa untuk kegiatan sehari-hari seperti berdoa untuk bepergian, berpakaian, masuk rumah atau kamar mandi, bercermin, perlindungan dan meminta harapan agar diberi keturunan

41 Departemen Agama Republik Indones, Alquran Dan Terjemahannya, Surat Maryam Ayat 18 (Jakarta: PT Restu Bumi, 1976-1977), 464. 
yang sholeh sholehah. Doa tersebut termuat di dalam Alquran dan Alhadist sebagai pedoman manusia di era sekarang. Selain doa yang disebutkan di atas, Islam juga menganjurkan untuk berdoa dalam berhubungan badan pasangan suami-istri. Apabila pasangan suami-istri sebelum melakukan hubungan badan tetap ingat kepada Allah. Maka dapat diartikan bahwa calon anak yang dihasilkan nantinya akan mendapatkan perlindungan dari Allah SWT. Pernyataan tersebut sesuai dengan hadits yang termuat di dalam kitab shahih muslim, hadits nomor 2591 yang bertuliskan dibawah ini.

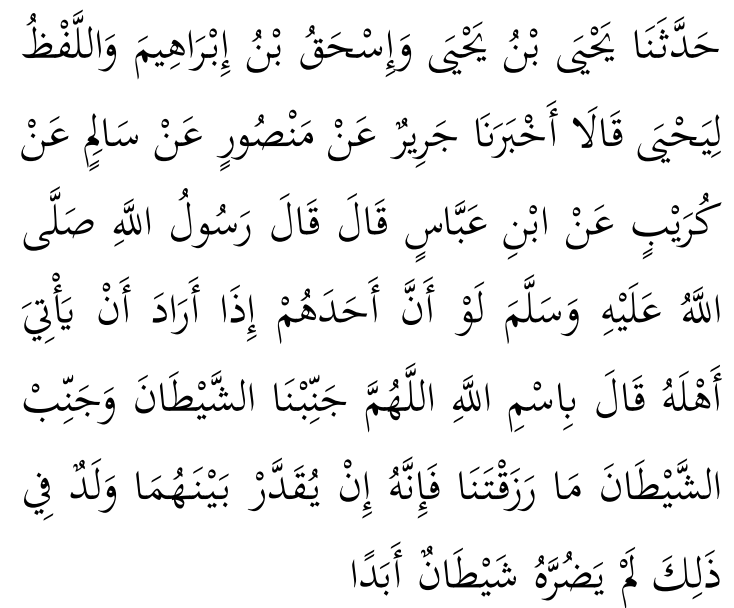

Artinya; Telah diceritakan kepada kami Yahya bin Yahya, Ishak bin Ibrahim. Dan lafadz yang kedua dari Yahya berkata, telah mengabarkan kepada kami Jarir dari Manshur dari Salim dari Kuraib dari Ibnu Abbas dia berkata, Rosulullah bersabda "Jika salah seorang dari kalian ingin mendatangi istrinya untuk berhubungan badan hendaknya mengucapkan, dengan menyebut nama Allah, Ya Allah jauhkanlah kami dari setan dan jauhkanlah setan dari apa anak yang akan Engkau rezekikan kepada kami. Apabila diantara keduanya

42 Saltanera, "Ensiklopedi Hadits-Kitab 9 Imam," dalam kitab Shahih Muslim, Nomor 2591, Ensiklopedi Hadits, 2010.

${ }^{43}$ Sugita Sugita and Kuswati Kuswati, "Pengaruh Konsumsi Buah Kurma Terhadap Peningkatan Kadar Hemoglobin Pada Ibu Hamil Trimester III," Jurnal ditakdirkan mendapatkan anak dari hasil persetubuhan itu, maka anak tersebut tidak akan dicelakakan setan selamanya." 42

\section{c) Tahapan Makanan Bergizi}

Perempuan hamil harus mengonsumsi makanan yang mencakup gizi lengkap dan seimbang. Tentu saja perihal tersebut sangat dibutuhkan untuk kesehatan janin yang tumbuh kembangnya membutuhkan makanan sehat dan sempurna. Ibnu Qayyim berpendapat bahwa makanan yang bergizi dan seimbang merupakan komponen penting yang mendukung tunbuh kembang janin dalam kandungan. Makanan yang bergizi dan seimbang merupakan nutrisi bagi janin, sehingga apapun yang dimakan oleh ibu akan masuk kedalam tubuh janin melalui plasenta. ${ }^{43}$ Maryam binti Imran juga diperintahkan untuk makan kurma sebagai asupan selama hamil, perihal ini sudah diabadikan dalam Alquran dari Surat Maryam Ayat 25.

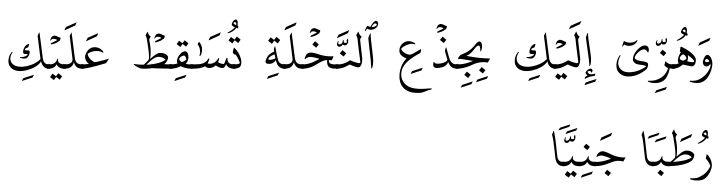

Artinya; Dan goyangkanlah pangkal pohon kurma itu ke arahmu, niscaya pohon itu kan menggugurkan buah kurma yang masak kepadamu. ${ }^{44}$

Merujuk pada ayat di atas bahwa buah kurma memiliki manfaat yang baik bagi perempuan hamil. Sementara ilmu gizi menjelaskan dari hasil uji laboratorium bahwa buah kurma mengandung $13,7 \mathrm{mg}$ zat besi yang mampu meningkatkan hemoglobin bagi perempuan hamil, sehingga ketika

Kebidanan dan Kesehatan Tradisional, Vol. 5, No. 1 (2020).

44 Departemen Agama Republik Indones, Alquran Dan Terjemahannya, Surat Maryam Ayat 25 (Jakarta: PT Restu Bumi, 1976-1977), 465. 
melahirkan akan terhindar dari yang namanya anemia dan mengakibatkan pendarahan yang berakibat fatal bagi keselamatan calon anak dan perempuan yang melahirkan. ${ }^{45}$ Berkaitan dengan perihal makanan yang dimakan Maryam binti Imran ketika proses hamil, di masa sekarang menjadi tradisi paling fundamental yang dijadikan kebiasan orang-orang Yahudi di wilayah Israel seperti ibu hamil dalam tradisi bangsa Yahudi mengonsumsi makanan bergizi, sebab makanan yang memiliki asupan gizi yang cukup dan seimbang akan membentuk janin sehat sehingga sel-sel otaknya akan tumbuh kembang dengan sehat. Otak yang sehat akan membuat proses belajar dalam masa pendidikan pranatal akan lebih mudah dan sesuai dengan tujuan dalam pembentukan kecerdasan. Sementara yang dikatakan makanan yang memiliki asupan gizi yang baik harus mengandung karbohidrat, protein, zat besi, lemak, vitamain $B$, dan magnesium. ${ }^{46}$

Berdasarkan pedoman dari ayat di atas dapat dipahami bahwa perempuan hamil disarankan untuk mengonsumsi lebih banyak zat besi. Tetapi bukan dimaknai sebagi patokan untuk mengonsumsi makanan yang mengandung zat besi saja. Apabila hal tersebut tetap dilakukan akan berakibat pada resiko buruk seperti perempuan hamil mengalami konstipasi, mual, muntah serta diare. Alhasil perempuan hamil diwajibkan untuk lebih selektif dalam pemilihan asupan gizi dari makanan yang dikonsumsi sehari-hari, sehingga harus dipastikan bahwa makanan yang dikonsumsi harus halal,

45 Sugita Sugita and Kuswati Kuswati, "Pengaruh Konsumsi Buah Kurma Terhadap Peningkatan Kadar Hemoglobin Pada Ibu Hamil Trimester III," Jurnal Kebidanan dan Kesehatan Tradisional, Vol. 5, No. 1 (2020). sehat dan memiliki gisi yang seimbang serta dapat memberikan manfaat dalam mendukung selama proses kehamilan yang sehat. Dalam proses kehamilan untuk menunjang kesehatan perempuan hamil dan mendukung tumbuh kembang janin dalam kandungan, ada beberapa nutrisi penting yang dianjurkan di antaranya, yang pertama asam folat, selama proses kehamilan perempuan hamil diwajibkan untuk mengonsumsi asam folat sebanyak 400-600 mcg per hari, hal ini sangat dibutuhkan dan berfungsi untuk mencegah janin mengalami cacat tabung saraf. Kedua protein, makanan yang mengandung protein memiliki manfaat besar bila dikonsumsi perempuan hamil yaitu untuk menunjang tumbuh kembang janin selama berada di dalam kandungan. Ketiga berserat, makanan jenis ini juga memiliki manfaat apabila dikonsumsi perempuan hamil yaitu untuk mencegah konstipasi dan wasir saat proses kehamilan. Keempat kalsium, asupan kalsium bagi perempuan hamil mempunyai manfaat untuk membentuk dan pertumbuhan tulang serta gigi bagi janin sehingga dapat terbentuk secara optimal. Kelima lemak, jenis makanan yang mengandung lemak apabila dikonsumsi perempuan hamil secara seimbang, maka akan mempunyai manfaat bagi janin dan perempuan yang hamil yaitu membantu dalam pembentukan otak dan saraf pusat pada janin yang masih berada dalam kandungan. ${ }^{47}$ Meskipun demikian, perempuan hamil harus lebih pintar dalam memilih makanan yang berlemak, pilihlah makanan yang

46 Miftahul Kasana and Sari, "Pendidikan Pranatal Yahudi Dan Relevansinya Dengan Pendidikan Islam", Jurnal Academica, Vol. 1, No. 2, (2017).

47 "Pentingnya Gizi Seimbang Bagi Ibu Hamil," RSIA Mutiara Bunda Salatiga, 2020, http://www.mutiarabundasalatiga.com/news/read/ pentingnya-gizi-seimbang-bagi-ibu-hamil/33. 
berlemak sehat seperti alpukat, keju, telur, kacang-kacangan dan minyak zaitun. Dengan demikian dapat diambil benang merah bahwa perempuan selama proses kehamilan sangat membutuhkan asupan dari berbagai makanan yang mengandung gizi seimbang untuk pertumbuhan janin agar optimal.

\section{KESIMPULAN}

Berpedoman pada beberapa ayat, teori dan uraian tesebut dapat dipahami bahwa Maryam binti Imran dan Hanna binti Faqudha dalam kisah Maryam telah memberikan contoh yang nyata dalam proses pendidikan pranatal secara perspektif Islam. Proses pendidikan pranatal yang dilakukan Maryam binti Imran dalam penelitian ini dapat digolongkan menjadi dua kategori yakni pendidikan pranatal secara psikis dan pendidikan pranatal secara fisik. Pendidikan pranatal secara psikis yang dilakukan Maryam binti Imran diawali dengan tahapan beribadah seperti berdzikir dan kegiatan ibadah lain, hal tersebut dilakukan karena ibadah yang dilakukan oleh perempuan hamil memiliki berbagai manfaat seperti kesehatan secara psikis dan fisik bagi perkembangan janin selama masih berada di dalam kandungan. Pendidikan pranatal secara fisik yang dilakukan Maryam binti Imran diawali dengan tahapan pemilihan jodoh yang memiliki kriteria utama yakni alim secara agama, dengan tujuan sifat-sifat yang dapat diwariskan seperti kecerdasasan spiritual, intelegensi dan tingkah lakunya akan menurun kepada anakanaknya yang akan dilahirkan, seperti yang diterapkan Hanna binti Fuqadha, yang sholehah dan alim melahirkan keturunan berupa Maryam binti Imran yang selalu berkhidmat di Baitul Maqdis.
Tahapan kedua adalah hubungan biologis yang harus disandarkan kepada Allah, dengan harapan kelak nantinya apabila diberikan rezeki berupa keturunan akan selalu diberi perlindungan dari gangguan setan sehingga anak dapat tumbuh menjadi sholeh-sholeh dan selalu taat kepada Allah, sebagaimana yang telah dilakukan Hanna binti Fuqadha dan Maryam binti Imran yang melakukan doa terus menerus untuk mendapatkan keturunan yang dapat meneruskan perjuangan mereka di jalan Allah. Alhasil terbukti Hanna binti Fuqadha diberi keturan Maryam binti Imran sebagai perempuan yang suci serta mulia, sementara Maryam binti Imran diberi keturunan yakni Isa putra Maryam yang sekaligus menjadi Nabi dari bangsa Yahudi. Tahapan ketiga adalah mengonsumsi makanan yang bergizi dan seimbang, dengan tujuan agar tumbuh kembang organ-organ vital dan jaringan saraf janin selama berada di dalam kandungan dapat tumbuh secara optimal. Apabila tahapan-tahapan yang pernah dicontohkan Maryam binti Imran dapat dilaksanakan dengan baik, maka dapat dikatakan janin yang masih berada di dalam kandungan terbentuk secara optimal baik secara psikis maupun fisik. Alhasil akan menciptakan manusia yang memiliki potensi yang luar biasa secara spiritual dan intelensi.

\section{REFERENSI}

Afif, Robi'ul Nurul Aini. "Implementasi Pendidikan Anak Pranatal." ZAHRA: Research And Tought Elmentary School Of Islam Journal 1 , no. 02 (2020).

Andiyanto, Tri. "Konsep Pendidikan Pranatal, Postnatal Dan Pendidikan Sepanjang Hayat." 
Elementary: Jurnal Ilmiah Pendidikan Dasar 4, no. 2 (2018).

Asqalani, Ibnu Hajar. Bulughul Marom. Semarang: Toha Putra, 1996.

Baihaqi. Mendidik Anak Dalam Kandungan. Jakarta: PT Grafindo Persada, 1996.

Departemen Agama Republik Indones. Alquran Dan Terjemahannya. Jakarta: PT Restu Bumi, 1976.

Ernawati, Aeda, Badan Perencanaan, Pembangunan Daerah, and Kabupaten Pati. "Masalah Gizi Pada Ibu Hamil Nutritional Issues among Pregnant Mothers" XIII, no. 1 (2019): 60-69.

Hasbullah. Dasar-Dasar IImu Pendidikan. Jakarta: PT Raja Grafindo Persada, 2009.

Ibnu Qayyim Al-Jauziyyah, Abu Abdillah Muhammad bin Abi Bakrin bin Ayyub. Tuhfah Al-Maudud Bi Ahkami Al-Maulud. 1st ed. Cairo: Daru Ibnu Al-Jauzi, 2021.

Ichromi, Rohman Nur. "Konsep Pendidikan Pranatal Menurut Dr. Mansur, M.A Dan Ubes Nur Islam." UIN Maulana Malik Ibrahim, 2016.

Ihsan, Fuad. Dasar-Dasar Pendidikan. Jakarta: Rineka Cipta, 2008.

Indrijati, Herdina, et.al. Psikologi Perkembangan \& Pendidikan Anak Usia Dini. Pertama. Jakarta: Kencana, 2016.

Islam, Ubes Nur. Mendidik Anak Dalam Kandungan, Optimalisasi Potensi Anak Sejak Dini. Jakarta: Gema Insani, 2004.

Izzaty, Rita Eka, et.al. Perkembangan Peserta Didik. Yogyakarta: UNY Press, 2008.
Langgulung, Hasan. Pendidikan Islam Dalam Abad Ke 21. Jakarta: PT. Pustaka Al- Husna Baru, 2003.

Mahmudah, Aeni. "Memilih Pasangan Hidup Dalam Perspektif Hadits (Tinjauan Teori Dan Aplikasi)." Diyah Al-Afkar 4, no. 1 (2016).

Mansur, Mendidik Anak Sejak Dalam Kandungan. Yogyakarta: Mirta Pustaka, 2006.

Masrom, Mizan Adiliah Binti. "Sosok Maryam Dalam Al-Quran (Studi Komparatif Antara Tafsir Ibnu Katsir Dan Tafsir Al-Misbah)." AtTibyan 1, no. 1 (2019): 1-18.

Masrur, Muhammad Shodiq, and Azka Salsabila. "Peran Agama Dalam Kesehatan Mental (Kajian Psikologis Atas Kisah Maryam Binti Imran Dalam QS Maryam: 18-22)." Akademika 14, no. 2 (2020): 1-12.

Miftahul Kasana, and Anggraeni Novita Sari. "Pendidikan Pranatal Yahudi Dan Relevansinya Dengan Pendidikan Islam." Academica: Journal of Multidisciplinary Studies 1, no. 2 (2017).

Mujahidin, Anwar, and Zamzam Farrihatul Khoiriyah. "Konsep Pendidikan Prenatal Dalam Perspektif Tafsir Al-Misbah Karya M.Quraish Shihab." Ta'allum: Jurnal Pendidikan Islam 06, no. 01 (2018).

Mursid. Kurikulum Dan Pendidikan Anak Usia Dini. Semarang: AKFI Media, 2010.

No Name, "Pentingnya Gizi Seimbang Bagi Ibu Hamil." RSIA mutiara bunda salatiga. Last modified 2020.

http://www.mutiarabundasalati 
ga.com/news/read/pentingnyagizi-seimbang-bagi-ibuhamil/33.

Putri, Fadhila Auliya Widia. "11 Manfaat Sholat Untuk Ibu Hamil Yang Jarang Diketahui Banyak Orang."

Saltanera. "Ensiklopedi Hadits-Kitab 9 Imam." Ensiklopedi Hadits, 2010.

Shihab, M. Quraisy. Tafsir Al-Mishbah (Pesan, Kesan Dan Keserasian Alquran. Jakarta: Lentera Hati, 2002.

Soyomukti, Nurori. Teori-Teori Pendidikan; Tradisional (Neo), Liberal, Marxis-Sosialis, Postmodern. Yogyakarta: ArRuzz Media, 2010.

Sugita, Sugita, and Kuswati Kuswati. "Pengaruh Konsumsi Buah Kurma Terhadap Peningkatan Kadar Hemoglobin Pada Ibu Hamil Trimester III." Jurnal Kebidanan dan Kesehatan Tradisional 5, no. 1 (2020): 5866.

Ulfa, Maria. "Metode Pertahanan Diri Bagi Perempuan Dan Hikmah Edukasi Dalam Kisah Maryam Binti Imran" 29, no. 2 (2017): 139-149.

Zed, Mustika. Metode Penelitian Kepustakaan. Jakarta: Yayasan Obor Indonesia, 2003. 
Pendidikan Pranatal Menurut Perspektif Islam dari Kisah Maryam | Muhammad Shodiq Masrur 